\title{
ANALISIS EXPECTATION GAP ANTARA APARAT PENGAWASAN INTERN PEMERINTAH (APIP) DAN PEMANGKU KEPENTINGAN MENGENAI PERAN DAN INDEPENDENSI APIP DALAM PENGAWASAN PENYUSUNAN ANGGARAN BELANJA DAERAH PADA PEMERINTAH PROVINSI SULAWESI UTARA
}

\author{
Yuanita Iva Maya Singal \\ David Paul E. Saerang \\ Herman Karamoy
}

(Email : iva.singal@yahoo.com)

\begin{abstract}
As an institution of supervision Inspectorate have a responsibility to review the drafting of RKA SKPD. In carrying out the functions of supervision, often found the existence of the expectation gap i.e. a difference of wishes or expectations of stakeholders towards the APIP work with the reality of the work shown by the APIP. Expectations of stakeholders sometimes exceeds what the roles and responsibilities of APIP. This research aims to analyze the expectation gap between APIP and stakeholders (auditee) regarding the role and independence of the APIP in supervision of the preparation of the regional budget in the Government of North Sulawesi province. This study used a qualitative approach by taking the location of research in 5 (five) SKPD on the Government of North Sulawesi province with criteria of informant is APIP in North Sulawesi Province of Inspectorate with experience more than 5 (five) years and auditee has the task drafting of RKA.

The results of this study showed that at the role of APIP, there is no an expectation gap but for the issue of perception the limitation of responsibility of APIP, need to be evaluated especially in things still lacking with regards to his responsibilities include improving the quality of human resources such as the understanding of the regulation and its changes and also their skill. Whereas toward independence, on the issue of the perception of the independence of APIP there is no expectation gap but about the influence of the organizational structure of the role and influence of the role of APIP as a consultant found the existence of the expectation gap.
\end{abstract}

Keywords : Expectation Gap, The Role Of APIP, Independence Of APIP, Supervision of The Formation Of The Regional Budget

\subsection{Latar Belakang}

\section{PENDAHULUAN}

Dengan berlakunya otonomi daerah, maka setiap daerah dapat mengatur sendiri daerahnya dan tidak tergantung lagi kepada pemerintah pusat. Hal ini menimbulkan konsekuensi yang berat bagi setiap kepala daerah dimana daerah harus mampu mengelola daerahnya termasuk keuangan daerah sesuai dengan prinsip tatakelola pemerintahan yang baik. Disamping itu, daerah dituntut untuk dapat menyusun perencanaan pembangunan daerah yang sejalan dengan perencanaan pembangunan nasional. Undang-undang Nomor 17 tahun 2003 tentang Keuangan Negara dan Undang-undang Nomor 25 tahun 2004 tentang Sistem Perencanaan Pembangunan Nasional (SPPN) mengamanatkan bahwa penyusunan APBD disusun sesuai dengan kebutuhan penyelenggaraan pemerintahan dan kemampuan pendapatan daerah dengan berpedoman kepada Rencana Kerja Pemerintah Daerah (RKPD) dalam rangka mewujudkan tercapainya tujuan bernegara.

Dalam buku Pedoman Pelaksanaan Reviu Dokumen Rencana Pembangunan dan Anggaran Tahunan Daerah (2016) dijelaskan bahwa berdasarkan hasil monitoring Direktorat Jenderal Bina Pembangunan Daerah Kementerian Dalam Negeri Tahun 2013, dokumen perencanaan pembangunan daerah belum menjadi landasan dalam penganggaran. Hal tersebut tergambar dari besarnya perbedaan (inkonsistensi) antara program dan pagu yang direncanakan dengan yang dianggarkan. Rencana Kerja Anggaran Satuan Kerja Perangkat Daerah (RKASKPD) masih banyak yang belum konsisten terhadap kaidah-kaidah perencanaan dan belum disusun dengan 
baik dan tepat sehingga dokumen Rencana Kerja Anggaran Satuan Kerja Perangkat Daerah seringkali menyimpang dari tujuan yang direncanakan. Oleh karena itu dipandang perlu dilakukan prosedur pengawasan mulai pada saat identifikasi kebutuhan dalam penyusunan Rencana Kerja Anggaran sebagaimana yang diamanatkan oleh undang-undang nomor 23 tahun 2014. Disinilah Inspektorat sebagai Aparat Pengawasan Internal Pemerintah (APIP) dituntut semakin nyata menunjukkan perannya.

Namun dalam prakteknya, APIP belum dapat memainkan perannya secara maksimal. Masih banyak kepala daerah dan sebagian aparat pemerintah daerah yang belum memahami sepenuhnya arti penting peran dan fungsi pengawasan yang dijalankan oleh Inspektorat. Banyak yang beranggapan bahwa auditor Inspektorat adalah pemeriksa yang hanya bertugas mencari-cari kesalahan auditi. Selain itu, pemangku kepentingan dalam hal ini Satuan Kerja Perangkat Daerah (SKPD) selaku auditi belum memahami arti peran APIP sebagai early warning. Dalam hal independensi, APIP di Inspektorat Provinsi Sulawesi Utara masih menemui banyak kendala di lapangan seperti misalnya kedudukan Inspektorat dalam struktur Organisasi Perangkat Daerah, Inspektorat adalah bagian integral dari Pemerintahan Daerah yang berada dibawah Kepala Daerah dimana berdasarkan Peraturan Menteri Dalam Negeri nomor 13 tahun 2006, Kepala Daerah melimpahkan sebagian atau seluruh kekuasaannya kepada Sekretaris Daerah selaku koordinator pengelolaan keuangan daerah dimana salah satu tugasnya adalah memberikan persetujuan pengesahan DPA SKPD induk dan perubahan, termasuk didalamnya DPA Inspektorat. Secara implisit, Inspektorat Provinsi Sulawesi Utara memiliki "ketergantungan" dalam hal anggaran terhadap Sekretaris Daerah. Sedangkan Sekretaris Daerah adalah kepala/pimpinan di SKPD Sekretariat Daerah yang adalah auditi/obyek pemeriksaan Inspektorat. Dalam urusan kepegawaian, Inspektorat Provinsi Sulawesi Utara sama seperti SKPD lainnya akan berurusan dengan Badan Kepegawaian Daerah (BKD). Hal-hal yang menyangkut administrasi kepegawaian baik pengangkatan, penempatan, kepangkatan, promosi, mutasi, pensiun dan lain-lain akan berurusan dengan BKD. Sedangkan dalam daftar obyek pemeriksaan Inspektorat, BKD pun termasuk salah satu obyek pemeriksaan/auditi.

Dalam kondisi demikian, APIP di Inspektorat Provinsi Sulawesi Utara tetap dituntut untuk menjaga kualitas perannya serta menjunjung tinggi profesionalitas dan independensi. Belum lagi ditambah dengan tingginya harapan para pemangku kepentingan terhadap APIP yang terkadang melebihi apa yang menjadi peran dan tanggung jawab APIP. Peneliti tertarik dengan penelitian tentang expectation gap karena ingin mengetahui apakah terdapat expectation gap antara APIP dan pemangku kepentingan mengenai peran dan independensi APIP. Selain itu peneliti juga ingin mengetahui bagaimana persepsi APIP dan pemangku kepentingan mengenai peran dan independensi APIP dalam pengawasan penyusunan anggaran belanja daerah pada pemerintah provinsi Sulawesi Utara.

Berdasarkan latar belakang tersebut, peneliti tertantang untuk melakukan penelitian dengan judul "Analisis Expectation Gap Antara Aparat Pengawasan Intern Pemerintah (Apip) Dan Pemangku Kepentingan Mengenai Peran Dan Independensi Apip Dalam Pengawasan Penyusunan Anggaran Belanja Daerah Pada Pemerintah Provinsi Sulawesi Utara".

\subsection{Rumusan Masalah}

Berdasarkan uraian dalam latar belakang masalah di atas, maka rumusan masalah dalam penelitian ini adalah :

1. Apakah terdapat expectation gap antara APIP dan pemangku kepentingan mengenai peran dan independensi APIP dalam Pengawasan Penyusunan Anggaran Belanja Daerah Pada Pemerintah Provinsi Sulawesi Utara.

2. Bagaimanakah persepsi APIP dan pemangku kepentingan mengenai peran dan independensi APIP dalam Pengawasan Penyusunan Anggaran Belanja Daerah Pada Pemerintah Provinsi Sulawesi Utara.

\section{TINJAUAN PUSTAKA}

\subsection{Teori Agency}

Teori keagenan (Agency theory) yang dikemukakan oleh Jensen Michael C. dan William H. Meckling pada tahun 1976 menyatakan adanya hubungan kerja antara pihak yang memberi wewenang (prinsipal) yaitu investor dengan pihak yang menerima wewenang (agensi) yaitu manajer dalam bentuk kontrak kerja sama. Implikasi penerapan teori ini dapat menimbulkan perilaku efisiensi atau perilaku opportunistik bagi si Agen. 
Pemerintah dalam menjalankan roda pemerintahan mengemban satu tanggung jawab yang besar yaitu melaksanakan pembangunan dan pelayanan publik untuk mewujudkan kesejahteraan rakyat. Anggaran yang digunakan dalam penyelenggaraan pemerintahan adalah anggaran publik karena bersumber dari masyarakat dan harus digunakan untuk sebesar-besarnya kepentingan masyarakat/publik. Sehingga dalam pengelolaan anggaran, pemerintah harus mengelolanya dengan ekonomis, efisien, efektif serta akuntabel. Sehingga dalam kondisi ini, pemerintah bertindak sebagai agen dan masyarakat sebagai principal. Dalam proses penyusunan anggaran, pihak agen dalam hal ini Pemerintah Daerah wajib menyusun perencanaan program yang pro rakyat dan mempertanggungjawabkan setiap rupiah yang digunakan untuk pelaksanaan pembangunan dan pelayanan publik kepada masyarakat sebagai principal.

\subsection{Teori Persepsi}

Muchlisin Riadi dalam kajianpustaka.com menjelaskan terbentuknya persepsi dimulai dengan pengamatan yang melalui proses hubungan melihat, mendengar, menyentuh, merasakan dan menerima sesuatu hal yang kemudian seseorang menseleksi, mengorganisasi, dan menginterpretasikan informasi yang diterimanya menjadi suatu gambaran yang berarti. Terjadinya pengamatan ini dipengaruhi oleh pengalaman masa lampau dan sikap seseorang dari individu.

Persepsi berkaitan erat dengan harapan (ekspektasi), persepsi yang berbeda dapat melahirkan harapan yang berbeda pula. Dalam penelitian ini, teori persepsi digunakan untuk menganalisis persepsi APIP dan pemangku kepentingan (dalam hal ini auditi) mengenai peran dan independensi APIP dalam pengawasan penyusunan anggaran belanja daerah pada pemerintah provinsi Sulawesi Utara serta menganalisis expectation gap yang ditimbulkannya.

\subsection{Teori Peran (Role Theory)}

Menurut Kahn dalam Agustina Lidya (2009) teori peran (role theory) merupakan penekanan sifat individual sebagai pelaku sosial yang mempelajari perilaku yang sesuai dengan posisi yang ditempati di masyarakat. Peran mencerminkan posisi seseorang dalam sistem sosial dengan hak dan kewajiban, kekuasaan dan tanggung jawab yang menyertainya. Masing-masing peran menghendaki perilaku yang berbeda - beda.

Dalam menjalankan peran, terkadang ada juga tekanan peran. Hardy \& Conway dalam Agustina Lidya (2009) mendefinisikan "role stress as a social structure condition in which role obligations are vague, difficult, conflicting or impossible to meet." Tekanan peran pada hakekatnya merupakan suatu kondisi dimana setiap peranan seseorang memiliki harapan yang berbeda yang dipengaruhi oleh harapan orang lain, yang mana harapan - harapan tersebut dapat berbenturan, tidak jelas dan menyulitkan peranan seseorang, sehingga peranan seseorang menjadi samar-samar, sulit, bertentangan atau tidak mungkin untuk bertemu. Dalam praktek dilapangan sering terjadi dimana seseorang memainkan lebih dari satu peran, sehingga tidak jarang terjadi konflik peran (role conflict). Arfan Ikhsan dan Muhammad Ishak dalam Agustina Lidya (2009) menyatakan bahwa konflik peran timbul karena adanya dua "perintah" berbeda yang diterima secara bersamaan dan pelaksanaan atas salah satu perintah saja akan mengakibatkan diabaikannya perintah yang lain.

Peran ganda APIP sebagai konsultan sekaligus sebagai pengawas, telah menempatkan APIP pada suatu kondisi dimana setiap peranan memiliki harapan yang berbeda dan sangat bertolak belakang. APIP dituntut untuk bersikap profesional sebagai pengawas dan tetap menjaga independensi dalam melaksanakan tugas. Namun disisi lain dengan adanya perubahan paradigma mengenai peran APIP, APIP diharapkan dapat menjadi konsultan yang menganut pola pendekatan mitra dengan auditi. Kondisi seperti ini dapat menyebabkan terjadinya konflik peran. Teori peran (role theory) digunakan untuk mengetahui pengaruh peran ganda APIP terhadap independensi dan menganalisis expectation gap yang ditimbulkannya.

\subsection{Expectation Gap}

Expectation gap adalah perbedaan antara keinginan atau harapan masyarakat terhadap hasil kerja auditor dengan hasil kerja yang ditunjukkan oleh auditor. Menurut Salehi et al., dalam Setyorini Diah A. (2010), expectation gap terjadi ketika ada perbedaan di antara apa yang diharapkan publik dari auditor dan apa yang auditor mampu berikan. Penelitian terhadap expectation gap terbagi atas 2 (dua) kategori yaitu : 
expectation gap pada sektor swasta dan expectation gap pada sektor publik. Dalam penelitian ini, objek penelitian yang dipilih adalah pada sektor publik.

Pierce dan Kilcommins, Boyd et al., McEnroe dan Martens dalam Daud Zaidi Mat (2007 : 2) berpendapat bahwa adanya gap tersebut disebabkan oleh kesalahan interpretasi (misinterpretations) dan kesalahpahaman (misunderstanding) mengenai pengertian audit oleh pemakai jasa auditor. Pemakai jasa auditor tidak mengerti tentang fungsi audit dan aturan auditor, sehingga akibatnya mereka memiliki harapan yang tidak realistis (unrealistic expectation) terhadap auditor.

\subsection{Peran APIP}

Dalam Pedoman Pelaksanaan Review Dokumen Rencana Pembangunan dan Anggaran Tahunan Daerah (2016 : 4), dijelaskan bahwa peran Aparat Pengawas Internal Pemerintah telah mengalami pergeseran paradigma yaitu dari peran watch dog (sekedar mencari-cari kesalahan) bergeser menjadi lebih fokus pada unsur pengawasan yang bersifat preventif (pencegahan), consultative dan quality assurance, pada programprogram strategis yang mempunyai resiko tinggi terhadap penyimpangan, early warning systems, pendampingan dan pembinaan.

\subsection{Independensi APIP}

Peraturan Menteri PAN Nomor : PER/05/M.PAN/03/2008 tentang Standar Audit APIP pada butir 2100 menyebutkan bahwa "dalam semua hal yang berkaitan dengan audit, APIP harus independen dan para auditornya harus obyektif dalam pelaksanaan tugasnya. Independensi APIP serta obyektifitas auditor diperlukan agar kredibilitas hasil pekerjaan APIP meningkat. Penilaian independensi dan obyektifitas mencakup dua komponen berikut : 1). Status APIP dalam organisasi; 2). Kebijakan untuk menjaga obyektifitas auditor terhadap obyek audit." Salehi Mahdi (2009 :166) dalam penelitiannya mengenai "Audit Independence and Expectation Gap" di Iran mencatat beberapa faktor yang dapat mempengaruhi independensi yaitu kedekatan dengan klien/auditi, hubungan kekerabatan (hubungan darah ataupun pernikahan) dengan klien/auditi, pemberian barang atau pun service dari klien/auditi, hutang budi dan ketergantungan terhadap auditi dalam hal data dan konfirmasi lainnya.

\subsection{Anggaran Sektor Publik}

Mardiasmo (2009 : 61) menyatakan bahwa anggaran sektor publik merupakan instrumen akuntabilitas atas pengelolaan dana publik dan pelaksanaan program-program yang dibiayai dengan uang publik. Anggaran merupakan artikulasi dari hasil perumusan strategi dan perencanaan strategik yang telah dibuat. Tahap penganggaran menjadi sangat penting karena anggaran yang tidak efektif dan tidak berorientasi pada kinerja akan dapat menggagalkan perencanaan yang sudah disusun.

\subsection{Penelitian Terdahulu}

Permasalahan expectation gap telah menjadi suatu hal yang menarik untuk diteliti. Selain dalam sektor swasta, expectation gap pun dapat muncul dalam sektor publik. Hal ini dapat dilihat dari beberapa penelitian terdahulu yang penulis rangkum sebagai berikut :

1. Penelitian Onulaka Paul N. (2014)

Hasil yang diperoleh dari penelitian yang berjudul "Effect of Audit Expectation Gap in Nigerian Capital Market" menunjukkan adanya expectation gap yang signifikan dari sisi tanggung jawab auditor dalam mendeteksi dan mencegah kecurangan (fraud), juga adanya expectation gap karena pengaruh ketidaksempurnaan standar audit dan adanya audit expectation gap yang signifikan terhadap keandalan laporan audit dan jumlah transaksi yang terjadi di Pasar Modal Nigeria.

2. Penelitian Yandi Dwi Febri (2013)

Hasil yang diperoleh dari Penelitian yang berjudul "Analisis Variabel-variabel Audit Expectation Gap atas Hasil Audit BPK (Studi Empiris Pada Pemerintah Kota Jambi Tahun 2013)" menunjukkan tidak adanya Audit Expectation Gap dari sisi Pelaporan Audit, akuntabilitas, kompetensi auditor, materialitas, audit kinerja dan opini wajar dari BPK antara auditor BPK provinsi Jambi dan pengguna laporan keuangan daerah di 
Pemerintah Kota Jambi. Namun dari sisi independensi dan bukti audit terdapat Audit Expectation Gap antara auditor BPK dan pengguna laporan keuangan daerah.

3. Penelitian Agyei Albert, et al. (2013)

Hasil yang diperoleh dari Penelitian yang berjudul "An Assessment of Audit Expectation Gap in Ghana" menunjukkan adanya audit expectation gap di Ghana khususnya menyangkut tanggung jawab auditor dalam mendeteksi kecurangan dan keandalan struktur pengendalian internal dari entitas yang diaudit.

4. Penelitian Setyorini Diah A. (2010)

Hasil yang diperoleh dari Penelitian yang berjudul "Analisis Audit Expectation Gap Pada Pemerintah Daerah (Studi Empiris di Kabupaten Sragen)", menunjukkan adanya audit expectation gap antara auditor BPK dan pengguna laporan keuangan pemerintah (anggota DPRD, pegawai DPPKAD dan masyarakat pembayar pajak) dilihat dari sisi peran auditor, independensi auditor dan pengetahuan audit.

5. Penelitian Salehi Mahdi et al. (2009)

Hasil yang diperoleh dari penelitian yang berjudul "Audit Independence and Expectation Gap : Empirical Evidence from Iran" menunjukkan adanya expectation gap yang signifikan antara auditor dan investor di Iran mengenai independensi audit. Semakin independen seorang auditor, maka akan semakin percaya diri dalam pekerjaannya dan pemberian opini. Independensi merupakan faktor penting untuk mengurangi audit expectation gap.

\section{Penelitian Daud Zaidi Mat (2007)}

Hasil yang diperoleh dari penelitian yang berjudul "The Study of the Audit Expectations Gap in the Public Sector of Malaysia" menunjukkan adanya perbedaan pandangan antara auditor dan Public Account Committee (PAC) member dan pengguna lain mengenai peran auditor dalam mendeteksi kecurangan (fraud), expectation gap dari sisi independensi auditor, kompetensi auditor, etika auditor, laporan audit dan standar audit.

\section{KERANGKA KONSEPTUAL}

Dari berbagai penelitian terdahulu mengenai expectation gap, menunjukkan bahwa perbedaan persepsi turut berkontribusi terhadap munculnya expectation gap. Daud Zaidi Mat (2007) menyebutkan bahwa "It is recognised that the gap exists due to differences in the perceptions of auditors and users over the audit functions and audit processes.

Melihat besarnya pengaruh persepsi terhadap expectation gap, maka dalam penelitian ini peneliti menetapkan indikator perbedaan persepsi sebagai salah satu faktor untuk menganalisis expectation gap baik terhadap peran maupun independensi APIP. Sebagaimana telah dijelaskan dalam bab sebelumnya, bahwa paradigma peran APIP telah mengalami perubahan dari watchdog yang hanya sekedar mencari-cari kesalahan kini bergeser menjadi lebih fokus pada unsur pencegahan (preventif), konsultan dan quality assurance. Pada unsur pencegahan, APIP dituntut berperan sebagai early warning system, yang akan memberikan peringatan dini kepada pemangku kepentingan dalam hal ini SKPD sebagai auditi. Dalam melaksanakan tugas pengawasan penyusunan RKA atau yang dikenal dengan review RKA, APIP di Inspektorat Provinsi Sulawesi Utara memiliki batasan-batasan sebagaimana yang telah diatur dalam Standar Operasional Prosedur (SOP) Pengawasan Inspektorat Provinsi Sulawesi Utara. Dalam SOP itu juga menjelaskan tentang dokumendokumen yang digunakan sebagai dasar penyusunan RKA serta sasaran pelaksanaan review RKA.

Dari sisi independensi, perbedaan persepsi tentang independensi juga digunakan untuk menganalisis expectation gap antara APIP dan pemangku kepentingan. Selain menganalisis pemahaman independensi secara definitif, penelitian ini menganalisis independensi dalam pengertian normatif yaitu situasi dan kondisi yang independen sebagaimana yang diatur dalam Peraturan Menteri PAN Nomor : PER/05/M.PAN/03/2008 tentang Standar Audit APIP yaitu posisi APIP ditempatkan secara tepat sehingga bebas dari intervensi dan memperoleh dukungan yang memadai dari pimpinan tertinggi organisasi. Penelitian ini akan menganalisis pengaruh kedudukan atau posisi APIP sesuai struktur Organisasi Perangkat Daerah saat ini terhadap independensi APIP. Selain itu, peran ganda APIP sebagai konsultan sekaligus sebagai pengawas juga merupakan salah satu faktor yang digunakan untuk menganalisis pengaruhnya terhadap independensi APIP. Jika pengaruh struktur Organisasi Perangkat Daerah dan peran ganda ini melemahkan independensi APIP 
maka terdapat kemungkinan kedua faktor ini berpengaruh terhadap expectation gap. Jadi, dalam penelitian ini peneliti akan menyoroti 2 (dua) pokok permasalahan yaitu :

1) Expectation gap antara APIP dan pemangku kepentingan mengenai peran APIP

2) Expectation gap antara APIP dan pemangku kepentingan mengenai independensi APIP

\section{METODE PENELITIAN}

Penelitian ini menggunakan pendekatan kualitatif dimana menurut Satori Djam'an et al. (2009 : 25) menyebutkan bahwa penelitian kualitatif adalah suatu pendekatan penelitian yang mengungkap situasi sosial tertentu dengan mendeskripsikan kenyataan secara benar, dibentuk oleh kata-kata berdasarkan teknik pengumpulan dan analisis data yang relevan yang diperoleh dari situasi yang alamiah.

Penentuan sumber data pada penelitian kualitatif dilakukan secara purposive yaitu ditentukan dengan menyesuaikan pada tujuan penelitian atau tujuan tertentu. Objek penelitian dalam penelitian kualitatif ini tidak dibatasi dengan banyaknya atau jumlah responden (Satori Djam'an et al. (2009 : 50)).

Lokasi penelitian ini adalah di lingkup Pemerintah Provinsi Sulawesi Utara yang terdiri dari 5 (lima) SKPD yaitu Badan Perencanaan dan Pembangunan Daerah (BAPPEDA), Badan Pengelolaan Keuangan dan Barang Milik Daerah (BPKBMD), Dinas Perikanan dan Kelautan, Badan Kepegawaian Daerah dan Inspektorat Provinsi Sulawesi Utara. Kriteria pemilihan SKPD ditentukan berdasarkan keterkaitan dengan tujuan penelitian ini yaitu sebagai berikut : SKPD yang memiliki tugas pokok terkait perencanaan baik program maupun keuangan sehingga membantu dalam menggali informasi terkait perencanaan, SKPD yang memiliki anggaran besar dan secara otomatis memiliki resiko besar, SKPD yang memiliki kewenangan dalam administrasi kepegawaian secara keseluruhan di lingkup Pemerintah Provinsi Sulawesi Utara untuk melihat pengaruh kewenangan tersebut terhadap independensi APIP.

Pengumpulan data dilakukan melalui observasi, wawancara semi struktur dengan para informan dan studi dokumen dan dengan melakukan triangulasi. Teknik analisis data yang digunakan adalah deskriptif naratif. Teknik ini menurut Miles dan Hubermen dalam Satori Djam'an et al. (2009 : 39) diterapkan melalui :

1. Tahap Pengumpulan Data yaitu proses memasuki lingkungan penelitian dan melakukan pengumpulan data penelitian.

2. Tahap Reduksi Data yaitu proses pemilihan, pemusatan perhatian pada penyederhanaan, pengabstrakan dan transformasi data kasar yang muncul dari catatan-catatan tertulis dari lapangan.

3. Tahap Penyajian Data yaitu penyajian informasi untuk memberikan kemungkinan adanya penarikan kesimpulan dan pengambilan tindakan.

4. Tahap Penarikan Kesimpulan/verifikasi yaitu penarikan kesimpulan dari data yang telah dianalisis.

\section{ANALISIS DAN PEMBAHASAN HASIL PENELITIAN}

Sesuai Permendagri Nomor 52 tahun 2015 tentang Pedoman Penyusunan Anggaran Pendapatan dan Belanja Daerah Tahun Anggaran 2016 menyebutkan bahwa dalam rangka peningkatan kualitas perencanaan penganggaran dan menjamin kepatuhan terhadap kaidah-kaidah penganggaran sebagai quality assurance, Kepala Daerah harus menugaskan APIP untuk melakukan review atas RKA-SKPD. Review tersebut dilakukan bersamaan dengan proses pembahasan RKA-SKPD oleh Tim Anggaran Pemerintah Daerah (TAPD).

Dalam pelaksanaan review RKA ini, Inspektorat Provinsi Sulawesi Utara telah menyusun Standar Operasional Prosedur (SOP) yang menjadi pedoman review RKA-SKPD bagi para APIP. Sesuai Pedoman Pelaksanaan Review Dokumen Rencana Pembangunan dan Anggaran Tahunan Daerah, pelaksanaan review atas dokumen perencanaan pembangunan dan penganggaran bertujuan untuk memberi keyakinan terbatas mengenai akurasi, keandalan dan keabsahan terhadap :

a) Informasi dalam RKPD sesuai dengan RPJMD;

b) Informasi dalam Renja-SKPD sesuai dengan RKPD;

c) Informasi dalam KUA dan PPAS sesuai dengan RKPD;

d) Informasi dalam RKA-SKPD sesuai dengan PPAS dan Renja-SKPD; dan

e) Perumusan dokumen rencana pembangunan dan anggaran tahunan daerah telah sesuai dengan tata cara dan kaidah-kaidah perencanaan dan penganggaran. 
Seperti yang telah dijelaskan dalam bab sebelumnya, penelitian ini akan menyoroti 2 (dua) pokok permasalahan yaitu :

1) Expectation gap antara APIP dan pemangku kepentingan mengenai peran APIP

2) Expectation gap antara APIP dan pemangku kepentingan mengenai independensi APIP Adapun hasil penelitian yang diperoleh diuraikan lebih lanjut dalam sub bab berikut :

\subsection{Expectation gap antara APIP dan pemangku kepentingan mengenai peran APIP}

Untuk mengetahui persepsi APIP dan pemangku kepentingan mengenai peran APIP dalam pengawasan penyusunan anggaran belanja daerah, penulis menyoroti 5 (lima) permasalahan terkait peran APIP, yaitu :

\subsubsection{Persepsi Mengenai Perubahan Paradigma Peran APIP}

Indikator 1 : terdapat expectation gap mengenai peran APIP jika ada perbedaan persepsi antara APIP dan pemangku kepentingan (auditi) mengenai perubahan paradigma peran APIP.

Ketidakpahaman auditi terhadap perubahan paradigma peran APIP dapat mengerdilkan peran APIP di mata pemangku kepentingan dalam hal ini SKPD selaku auditi. Dari hasil wawancara terlihat bahwa APIP menyadari dalam melaksanakan tugas pengawasan baik audit, review, monitoring dan tugas pengawasan yang lain, tugas APIP itu bukan hanya terbatas pada mencari-cari kesalahan tetapi juga memberikan saran untuk pencegahan dan arahan dalam rangka pembinaan dengan pendekatan mitra namun bukan berarti menyalahgunakan arti dari "pembinaan" tersebut, artinya bila terdapat temuan yang substantif dan material harus ditindak tegas bukan lagi sekedar membina. Namun, harus diakui masih ada juga individu-individu yang melakukan pemeriksaan dengan mengikuti pendekatan paradigma lama (watchdog). Dari pendapat para auditi terlihat bahwa mereka sudah merasakan perbedaan pola pemeriksaan dalam kerangka paradigma baru yang lebih fokus kepada pencegahan dan pembinaan bahkan ada yang memandang APIP sebagai mitra SKPD karena APIP banyak memberikan edukasi, bimbingan dan arahan untuk menjaga SKPD yang adalah auditinya agar tetap on the track.

Dari uraian tersebut, dapat disimpulkan bahwa tidak terdapat perbedaan persepsi antara APIP dan auditi mengenai perubahan paradigma peran APIP. APIP dan pemangku kepentingan dalam hal ini auditi sudah sama-sama mengetahui bahwa peran APIP bukan hanya sekedar mencari-cari kesalahan tetapi lebih fokus pada pencegahan, konsultatif dan quality assurance.

\subsubsection{Persepsi Tentang Peran APIP sebagai early warning system}

Indikator 2 : terdapat expectation gap mengenai peran APIP jika ada perbedaan persepsi antara APIP dan auditi tentang peran APIP sebagai early warning system.

Early warning system adalah wujud peran APIP dimana didalamnya terdapat unsur prevent (mencegah), deter (menghalangi) dan detect (mendeteksi). Dari hasil wawancara terlihat bahwa baik APIP maupun auditi memiliki persepsi yang sama mengenai peran APIP sebagai early warning system, dimana mereka berpendapat bahwa pencegahan harus dimulai dari tahap penyusunan anggaran. Kegiatan belanja yang tidak bisa di anggarkan, diharapkan tidak lagi ditata pada saat penyusunan Rencana Kerja Anggaran, untuk menghindari kesalahan-kesalahan diwaktu lalu dimana kegiatan sudah dilaksanakan namun tidak bisa dibayar karena kesalahan penganggaran. Inilah yang diharapkan dari peran APIP sebagai early warning system yaitu mencegah terjadinya kesalahan penganggaran, menghalangi segala bentuk penyimpangan dan pelanggaran terhadap peraturan perundang-undangan serta sejak dini dapat mendeteksi kecurangan.

Berdasarkan uraian tersebut dapat disimpulkan bahwa tidak terdapat perbedaan persepsi antara APIP dan auditi tentang peran APIP sebagai early warning system.

\subsubsection{Persepsi Mengenai Batasan Tanggung Jawab APIP}

Indikator 3 : terdapat expectation gap mengenai peran APIP jika ada perbedaan persepsi antara APIP dan pemangku kepentingan (auditi) mengenai batasan tanggung jawab APIP.

Hal ini untuk mengetahui persepsi APIP dan Auditi mengenai batasan tanggung jawab APIP bila masih terdapat temuan dari auditor BPK di SKPD yang sudah diperiksa oleh APIP. Hasil wawancara menunjukkan sebagian besar APIP dan auditi berpendapat bahwa pemangku kepentingan (auditi) bertanggung 
jawab apabila dikemudian hari masih terdapat temuan BPK setelah APIP melakukan pemeriksaan. Menurut mereka APIP sudah memberikan koreksi dan arahan-arahan yang diharapkan dapat dijadikan acuan untuk melakukan koreksi pada bidang/bagian yang tidak disampel. Hal ini sesuai dengan apa yang diatur dalam Standar Operasional Prosedur pelaksanaan review Rencana Kerja Anggaran Inspektorat Provinsi Sulawesi Utara yang kemungkinan belum diketahui oleh auditi, dimana dalam pemeriksaan dokumen hanya dilakukan pada sampel yang dipilih dengan cara, antara lain :

1) Berdasarkan SKPD yang memiliki anggaran besar;

2) Berdasarkan SKPD yang masih mempunyai permasalahan dalam penganggaran sebagaimana hasil audit BPK, BPKP dan APIP;

3) Berdasarkan SKPD yang memiliki program dan kegiatan yang menjadi skala prioritas.

Namun, walaupun tanggung jawab itu ada di pundak SKPD, salah seorang auditi berpendapat bahwa APIP juga seharusnya turut bertanggung jawab sebagai quality assurance terhadap kinerja SKPD yang sudah diperiksa oleh APIP. Berkaitan dengan pernyataan ini, auditi menyarankan APIP mengevaluasi hal-hal yang masih kurang berkaitan dengan peningkatan kualitas sumber daya manusia (SDM) yang perlu terus ditingkatkan skill dan teknik pemeriksaannya.

Berdasarkan uraian tersebut dapat disimpulkan bahwa tidak terdapat perbedaan persepsi antara APIP dan pemangku kepentingan (auditi) mengenai batasan tanggung jawab APIP, hanya saja APIP perlu mengevaluasi hal-hal yang masih kurang termasuk kualitas sumber daya manusia (SDM) APIP yang harus terus ditingkatkan skill dan teknik pemeriksaannya.

\subsubsection{Pemahaman Tentang Dokumen-dokumen Yang Menjadi Dasar Penyusunan RKA}

Indikator 4 : terdapat expectation gap mengenai peran APIP jika ada perbedaan pemahaman antara APIP dan auditi mengenai dokumen-dokumen yang menjadi dasar penyusunan RKA.

Hal ini untuk mengetahui tingkat pemahaman APIP dan Auditi mengenai dokumen-dokumen yang menjadi dasar dalam penyusunan Rencana Kerja Anggaran. Tingkat pemahaman APIP menjadi salah satu indikator yang ditetapkan penulis karena penulis berpendapat bahwa kompetensi memiliki hubungan erat dengan peran. Kompetensi yang dimaksud disini bukanlah hanya terbatas pada pengetahuan saja tapi juga termasuk skill, seperti pernyataan Daud Zaidi Mat (2007 : 74) berikut : “...auditor competence is determined by considering a set of relevant attributes such as knowledge, skill and attitudes". Jika pemahaman auditi mengenai dokumen-dokumen pendukung dalam penyusunan RKA, melebihi pemahaman/kompetensi APIP maka peran APIP pasti tidak maksimal bahkan bisa menjadi bahan olokan di lapangan.

Dari hasil wawancara terlihat bahwa baik APIP maupun auditi memahami dokumen-dokumen yang digunakan sebagai acuan dalam penyusunan Rencana Kerja Anggaran, sekalipun tidak semua dapat menyebutkan satu persatu dokumen yang digunakan sebagai acuan namun secara keseluruhan baik APIP maupun auditi paham bahwa dalam penyusunan Rencana Kerja Anggaran ada dokumen-dokumen yang harus dijadikan dasar sesuai aturan yang ditetapkan dalam Peraturan Menteri Dalam Negeri Nomor 13 tahun 2006 tentang Pedoman Pengelolaan Keuangan Daerah diantaranya yaitu Pedoman Penyusunan APBD yang dikeluarkan Mendagri setiap tahun anggaran, Standar Satuan Harga, draft Rencana Kerja Anggaran, Analisa Standar Belanja ,Tugas dan Fungsi SKPD, Rencana Kerja SKPD, Standar Biaya Masukan, Rencana Kerja Pemerintah Daerah, Kebijakan Umum Anggaran dan Prioritas Plafon Anggaran Sementara.

Dengan demikian, kesimpulan yang diperoleh adalah tidak terdapat perbedaan pemahaman antara APIP dan auditi mengenai dokumen-dokumen yang menjadi dasar penyusunan Rencana Kerja Anggaran.

\subsubsection{Pemahaman Tentang Sasaran Review Rencana Kerja Anggaran}

Indikator 5 : terdapat expectation gap mengenai peran APIP jika ada perbedaan pemahaman antara APIP dan auditi tentang sasaran Review RKA.

Pertanyaan ini untuk mengetahui tingkat pemahaman APIP dan Auditi mengenai point-point yang menjadi sasaran review Rencana Kerja Anggaran. Hasil wawancara terlihat bahwa baik APIP maupun auditi sudah memahami sasaran atau fokus penilaian pada saat Inspektorat (APIP) melakukan Review Rencana Kerja Anggaran, sekalipun tidak secara detail namun secara keseluruhan sudah memiliki persepsi yang sama. 
Baik APIP maupun auditi berpendapat bahwa sasaran Review Rencana Kerja Anggaran adalah menilai efektifitas, ekonomis dan efisiensi suatu kegiatan, melihat kelengkapan pengisian dokumen Rencana Kerja Anggaran, pengujian kelayakan kegiatan untuk menghasilkan suatu tujuan, pengujian atas keselarasan antara Rencana Kerja Anggaran dengan KUA PPAS, pengujian atas penggunaan kode rekening, pengujian atas halhal yang dilarang untuk dianggarkan contohnya perluasan cakupan pemeliharaan kesehatan bagi Kepala Daerah dan Wakil Kepala Daerah, sinkronisasi program dengan RPJMD dan RKPD, serta ketaatan terhadap aturan/standarisasi yang ada.

Hasil wawancara dan analisa ternyata tidak terdapat perbedaan persepsi antara APIP dan pemangku kepentingan (auditi) mengenai pemahaman tentang sasaran review Rencana Kerja Anggaran.

\subsection{Expectation gap antara APIP dan pemangku kepentingan mengenai independensi APIP}

Untuk mengetahui persepsi APIP dan pemangku kepentingan mengenai independensi APIP dalam pengawasan penyusunan anggaran belanja daerah, peneliti menyoroti 3 (tiga) permasalahan terkait independensi APIP, yaitu :

\subsubsection{Persepsi Tentang Independensi APIP}

Indikator 1 : terdapat expectation gap mengenai independensi APIP jika ada perbedaan persepsi antara APIP dan auditi tentang independensi APIP.

Hasil wawancara terlihat APIP dan auditi memahami bahwa independensi adalah hal penting dalam pelaksanaan tugas pengawasan. APIP tahu bahwa ia wajib untuk tidak memihak dan menjaga objektifitasnya bahkan jika ditugaskan di SKPD yang memiliki hubungan kekerabatan sekalipun. Untuk menjaga independensinya, APIP menyadari bukan hanya tergantung pada pribadi APIP itu sendiri tetapi juga pihak terkait baik itu auditi, pimpinan APIP maupun Kepala Daerah untuk secara bersama mendukung independensi APIP dengan cara tidak mengintervensi pelaksanaan tugas APIP. Dalam standar umum 2110 Standar Audit APIP sesuai Peraturan Menteri PAN Nomor : PER/05/M.PAN/03/2008 dijelaskan bahwa dalam menunjang Independensi APIP, posisi APIP ditempatkan secara tepat sehingga bebas dari intervensi dan memperoleh dukungan yang memadai dari pimpinan tertinggi organisasi. Dari hasil wawancara, seorang auditi berpendapat bahwa untuk mendukung independensinya, APIP itu seharusnya ditempatkan di atas dalam arti kualitasnya harus lebih tinggi dari SKPD/auditi. APIP harus jujur, memiliki kompetensi dan skill yang mumpuni serta menguasai aturan, karena seorang pengawas kalau tidak menguasai aturan akan sulit disebut pengawas.

Dari uraian tersebut, disimpulkan bahwa secara normatif tidak terdapat perbedaan persepsi antara APIP dan auditi tentang independensi APIP. APIP dan auditi memiliki persepsi yang sama bahwa sebagai aparat pengawas, APIP harus menjaga independensinya dalam pengawasan penyusunan RKA.

\subsubsection{Pengaruh Struktur Organisasi Perangkat Daerah Sesuai Peraturan Pemerintah Nomor 41 Tahun 2007 Tentang Organisasi Perangkat Daerah terhadap Independensi APIP. \\ Indikator 2 : terdapat expectation gap mengenai independensi APIP jika struktur Organisasi Perangkat} Daerah (sesuai Peraturan Pemerintah nomor 41 Tahun 2007) memiliki pengaruh negatif terhadap independensi APIP.

Regulasi yang mengatur tentang organisasi perangkat daerah telah mengalami perubahan. Tahun 2016 pemerintah telah mengeluarkan Peraturan Pemerintah Nomor 18 Tahun 2016 sebagai pengganti Peraturan Pemerintah Nomor 41 Tahun 2007 tentang Organisasi Perangkat Daerah. Namun dalam penelitian ini, peneliti masih menggunakan PP Nomor 41 Tahun 2007 dalam pembahasan karena 2 (dua) alasan yaitu : 1). ketentuan mengenai kedudukan Inspektorat dalam Organisasi Perangkat Daerah antara peraturan yang lama dan baru memiliki kesamaan; 2).objek penelitian tentang analisis expectation gap mengenai peran dan independensi APIP diambil pada rentang waktu sebelum tahun 2016 dimana pada waktu itu masih menggunakan peraturan yang lama yaitu PP Nomor 41 Tahun 2007.

Ketentuan ini telah menempatkan kedudukan Inspektorat sebagai pengawas internal pada posisi yang dapat membiaskan independensinya. Padahal, dalam standar umum Peraturan Menteri PAN Nomor : PER/05/M.PAN/03/2008 tentang Standar Audit APIP disebutkan bahwa : "Dalam semua hal yang berkaitan dengan audit, APIP harus independen dan para auditornya harus obyektif dalam pelaksanaan tugasnya" 
(butir 2100); dan "Dalam menunjang independensi APIP, posisi APIP ditempatkan secara tepat sehingga bebas dari intervensi dan memperoleh dukungan yang memadai dari pimpinan tertinggi organisasi." (butir 2110).

Standar audit APIP ini mewajibkan APIP untuk menjaga independensinya dalam melaksanakan tugas pengawasan, namun PP Nomor 41 tahun 2007 belum mencerminkan dukungan terhadap independensi APIP. Hal ini dibuktikan dengan beberapa ketentuan yang tidak menunjang independensi APIP terdapat dalam peraturan organisasi perangkat daerah tersebut seperti berikut :

a. Pimpinan Inspektorat memiliki jabatan struktural eselon IIa sama dengan pimpinan SKPD lainnya yang adalah auditi (pasal 34 ayat 2)

b. Jabatan struktural Sekretaris Daerah (salah satu auditi Inspektorat) lebih tinggi dari pimpinan Inspektorat (Inspektur), dimana Sekretaris Daerah memiliki jabatan struktural eselon Ib sedangkan Inspektur IIa.

c. Inspektorat memiliki "ketergantungan" anggaran dari Pemerintah Daerah dimana tugas dan fungsi pengelolaan keuangan tersebut berada di salah satu auditi yaitu Badan Pengelola Keuangan dan Barang Milik Daerah (BPKBMD). Berdasarkan Peraturan Gubernur nomor 26 tahun 2012 tentang Uraian Tugas BPKBMD sebagaimana yang diuraikan dalam point 5.1.1 huruf c, salah satu tugas BPKBMD adalah membantu Gubernur dalam memegang pelaksanaan tugas umum pemerintahan daerah bidang pengelola keuangan dan barang milik daerah, dan salah satu fungsinya adalah mengesahkan Dokumen Pelaksanaan Anggaran (DPA) dan Dokumen Perubahan Pelaksanaan Anggaran SKPD termasuk Inspektorat.

d. APIP sehubungan dengan status kepegawaiannya memiliki "ketergantungan" terhadap pemerintah daerah dimana tugas dan fungsi di bidang kepegawaian daerah tersebut berada di salah satu auditi yaitu Badan Kepegawaian Daerah. Berdasarkan Peraturan Gubernur Sulawesi Utara Nomor 72 Tahun 2008 tentang tugas dan fungsi BKD sebagaimana yang diuraikan dalam point 5.1.1 huruf e, salah satu tugas dan fungsi BKD adalah penyelenggaraan urusan administrasi kesekretariatan, pengadaan, pengembangan, mutasi, pensiun, jaringan informasi, kesejahteraan, pembinaan dan pengawasan pegawai (termasuk pegawai Inspektorat).

Kondisi ini secara psikologis mempengaruhi sikap dan pola pikir APIP maupun auditi, misalnya muncul sifat menganggap remeh dari beberapa auditi dan dari sisi APIP ada sebagian yang merasa terintimidasi sehingga mengakibatkan munculnya keengganan, menurunnya rasa percaya diri dan rasa takut dimutasi.

\subsubsection{Pengaruh Peran APIP Sebagai Konsultan Terhadap Independensi APIP}

Indikator 3 : terdapat expectation gap mengenai independensi APIP jika peran APIP sebagai konsultan memiliki pengaruh negatif terhadap independensi APIP.

Dalam menjalankan perannya sebagai konsultan dengan pola pendekatan mitra, APIP tidak boleh mengabaikan perannya yang lain yaitu sebagai pengawas yang perlu bersikap tegas, menjunjung tinggi profesionalisme dan menjaga independensinya. Tuntutan profesionalisme yang tinggi terhadap APIP menjadi tantangan tersendiri yang tidak mudah untuk dilakoni dan harus disikapi dengan bijak. Menurut Daud Zaidi Mat (2007 : 69) : "The issue of auditor independence becomes complicated because the auditors usually perform more than one service such as external auditing, internal auditing and management advisory services (MAS) with the same clients". Masalah independensi menjadi sangat rumit karena harus memainkan lebih dari satu peran yang berbeda kepada auditi yang sama. Menurutnya lagi, "A majority of users perceived that offering MAS to auditees would impair auditor independence due the possibility of auditors of auditing their own work and establishing a close relationship with auditees." (Daud Zaidi Mat, 2007 : 180). Dari kutipan pernyataan tersebut, dapat dilihat bahwa sebagian besar user berpendapat bahwa pemberian konsultansi kepada auditi dapat melemahkan independensi APIP karena adanya kedekatan hubungan dengan auditi. Tugas ini menjadi berat karena kedua peran tersebut yakni peran sebagai konsultan dan peran sebagai pengawas adalah dua peran yang bertolakbelakang sifatnya.

Dalam Bab 2 telah dijelaskan bahwa dalam teori peran, masing-masing peran menghendaki perilaku yang berbeda-beda. Dalam menjalankan peran, terkadang ada juga tekanan peran. Hardy \& Conway dalam Agustina Lidya (2009) mendefinisikan: "role stress as a social structure condition in which role obligations are vague, difficult, conflicting or impossible to meet." Dengan kata lain tekanan peran adalah suatu kondisi struktur sosial dimana suatu peranan adalah samar-samar, sulit, bertentangan atau tidak mungkin untuk bertemu. Tekanan peran pada hakekatnya merupakan suatu kondisi dimana setiap peran seseorang memiliki 
harapan berbeda yang turut dipengaruhi oleh harapan orang lain, dimana harapan tersebut dapat berbenturan, tidak jelas dan menyulitkan orang yang memainkan peran tersebut. Sehingga peran seseorang menjadi samarsamar, sulit, bertentangan atau tidak mungkin untuk bertemu.

Dalam praktek dilapangan sering terjadi dimana seseorang memainkan lebih dari satu peran, sehingga tidak jarang terjadi konflik peran (role conflict). Arfan Ikhsan dan Muhammad Ishak dalam Agustina Lidya (2009) menyatakan bahwa konflik peran timbul karena adanya dua "perintah" berbeda yang diterima secara bersamaan dan pelaksanaan atas salah satu perintah saja akan mengakibatkan diabaikannya perintah yang lain.

Beranjak dari teori peran ini, maka dapat digambarkan bahwa dengan adanya perubahan paradigma peran, APIP di"perintah" untuk menjalankan dua peran berbeda yaitu peran sebagai konsultan dan peran sebagai pengawas secara bersamaan. Daud Zaidi Mat (2007 p.70) dalam penelitiannya terhadap expectation gap di Malaysia menyebutkan : "the auditor practise of providing non-audit service and pressures of stakeholders on auditors are determining factors that contribute to the audit expectation gap in the private sector." (Praktik pemberian konsultansi dan tekanan dari stakeholder kepada auditor adalah faktor-faktor yang berkontribusi terhadap audit expectation gap di sektor swasta).

Peran ganda yang harus dilakoni APIP ini menimbulkan konflik peran di dalam diri APIP sehingga bisa menyebabkan terjadinya ambiguitas peran yang pada akhirnya dapat berpengaruh pada semakin kaburnya independensi APIP.

\subsection{Kesimpulan}

\section{KESIMPULAN DAN SARAN}

Berdasarkan hasil wawancara, pengamatan dan studi dokumen yang penulis lakukan maka kesimpulan dalam penelitian ini adalah sebagai berikut :

1. Tidak terdapat expectation gap mengenai peran APIP dalam pengawasan penyusunan anggaran belanja daerah pada Pemerintah Provinsi Sulawesi Utara namun untuk permasalahan tentang persepsi mengenai batasan tanggung jawab APIP, walaupun tidak terdapat expectation gap, APIP perlu mengevaluasi hal-hal yang masih kurang berkaitan dengan tanggung jawabnya termasuk peningkatan kualitas sumber daya manusia (SDM) seperti pemahaman tentang regulasi dan perubahannya, skill dan teknik pemeriksaannya berkaitan dengan perannya sebagai quality assurance. Adapun uraiannya sebagai berikut :

a. Tidak terdapat perbedaan persepsi antara APIP dan auditi mengenai perubahan paradigma peran APIP. APIP dan pemangku kepentingan dalam hal ini auditi sudah sama-sama mengetahui bahwa peran APIP bukan hanya sekedar mencari-cari kesalahan tetapi lebih fokus pada pencegahan, konsultatif dan quality assurance.

b. Tidak terdapat perbedaan persepsi antara APIP dan auditi tentang peran APIP sebagai early warning system.

c. Tidak terdapat perbedaan persepsi antara APIP dan pemangku kepentingan (auditi) mengenai batasan tanggung jawab APIP, hanya saja APIP perlu mengevaluasi hal-hal yang masih kurang termasuk kualitas sumber daya manusia APIP yang harus terus ditingkatkan skill dan teknik pemeriksaannya.

d. Tidak terdapat perbedaan pemahaman antara APIP dan auditi mengenai dokumen-dokumen yang menjadi dasar penyusunan RKA .

e. Tidak terdapat perbedaan persepsi antara APIP dan pemangku kepentingan (auditi) mengenai pemahaman tentang sasaran review RKA .

2. Terhadap permasalahan pengaruh struktur organisasi perangkat daerah (sesuai Peraturan Pemerintah Nomor 41 Tahun 2007) terhadap independensi APIP dan pengaruh peran APIP sebagai konsultan terhadap independensi APIP terdapat expectation gap namun atas permasalahan persepsi tentang independensi APIP tidak terdapat expectation gap. Adapun uraiannya sebagai berikut :

a. Tidak terdapat perbedaan persepsi antara APIP dan auditi tentang independensi APIP. APIP dan auditi memiliki persepsi yang sama bahwa sebagai aparat pengawas, APIP harus menjaga independensinya dalam pengawasan penyusunan RKA.

b. Struktur organisasi perangkat daerah sesuai peraturan pemerintah nomor 41 Tahun 2007 berpengaruh negatif terhadap independensi APIP dalam hal :

- Dapat memicu munculnya sifat memandang rendah/menganggap remeh dari pihak auditi; 
- APIP merasa terintimidasi secara psikologis sehingga timbul rasa takut karirnya terancam, enggan atau bahkan menjadi tidak percaya diri;

c. Peran APIP sebagai konsultan berpengaruh negatif terhadap independensi APIP karena mempengaruhi secara psikologis dengan terjalinnya pertemanan dan kedekatan dengan auditi, disamping itu peran ganda yang harus dilakoni APIP ini menimbulkan konflik peran di dalam diri APIP sehingga bisa menyebabkan terjadinya ambiguitas peran yang pada akhirnya dapat berpengaruh pada semakin kaburnya independensi APIP.

\subsection{Saran}

Berdasarkan hasil pembahasan dan kesimpulan yang diperoleh, ada beberapa saran yang dapat peneliti sampaikan dan diharapkan dapat diaplikasikan untuk mencegah makin besarnya expectation gap antara APIP dan pemangku kepentingan serta meminimalisasi dampak/pengaruh yang ditimbulkannya terhadap kualitas pengawasan di lingkup pemerintah provinsi Sulawesi Utara. Beberapa saran tersebut sebagai berikut :

1. Inspektorat Provinsi Sulawesi Utara perlu melakukan sosialisasi yang lebih intens kepada pemangku kepentingan (dalam hal ini SKPD selaku auditi) mengenai peran dan independensi APIP sehingga dapat dipahami secara menyeluruh oleh auditi.

2. APIP perlu terus mengupgrade kompetensinya melalui Diklat, Pelatihan dan Bedah Peraturan Baru untuk memenuhi tuntutan perkembangan dan tanggung jawab tugasnya. Disamping itu, dalam penerimaan pegawai di lingkup Inspektorat Provinsi Sulawesi Utara perlu diatur secara khusus baik kualifikasi pendidikan, keahlian maupun pengalaman harus benar-benar sesuai dengan kebutuhan tugas sebagai aparat pengawas.

3. Untuk memaksimalkan perannya sebagai konsultan sekaligus pengawas, Inspektorat Provinsi Sulawesi Utara perlu melakukan pembagian 2 (dua) divisi yaitu : divisi konsultan dan divisi pengawas. Dimana orang-orang yang duduk dalam divisi konsultan berbeda dengan divisi pengawas, sehingga peran ganda tersebut dapat berjalan dengan baik dan independensi APIP tetap terjaga.

4. Untuk menunjang independensinya, kedudukan Inspektorat dalam Organisasi Perangkat Daerah perlu dilakukan peninjauan kembali.

5. Kepala Daerah dan Pimpinan APIP wajib terus mendukung independensi APIP terutama dari halhal yang mengancam independensi tersebut misalnya mutasi APIP karena adanya konflik kepentingan (conflict of interest).

\subsection{Keterbatasan}

Dalam penelitian ini terdapat beberapa keterbatasan yang ditemui seperti :

1. Jumlah informan yang masih kurang karena hanya dibatasi pada pejabat struktural saja yang sebagian besar memiliki tingkat pengetahuan dan pemahaman memadai sehingga persepsi para informan mengenai peran dan independensi APIP tidak jauh berbeda dengan persepsi APIP itu sendiri. Sedangkan informan pada tingkat staf dalam penelitian ini hanya 1 (satu) orang sehingga belum dapat mewakili pendapat pemangku kepentingan (auditi) untuk semua tingkatan.

2. Terdapat kelemahan dalam menggali pendapat informan dengan metode wawancara yang bertatapan muka secara langsung karena informan bisa saja merasa sungkan ataupun malu untuk mengungkapkan pendapat sebenarnya, sehingga jawaban yang diberikan dapat saja bersifat formalitas dan tidak menggambarkan kondisi riil di lapangan.

\section{DAFTAR PUSTAKA}

Agyei Albert, Baah Kusi Aye, Ebenezer Owusu-Yeboah, 2013, An Assessment of Audit Expectation Gap in Ghana, International Journal of Academic Research in Accounting, Finance and Management Sciences Vol.3, No.4 Tahun 2013. 
Agustina Lidya, 2009, Pengaruh Konflik Peran, Ketidakjelasan Peran, dan Kelebihan Peran terhadap Kepuasan Kerja dan Kinerja Auditor (Penelitian pada Kantor Akuntan Publik yang Bermitra Dengan Kantor Akuntan Publik Big Four di Wilayah DKI Jakarta), Jurnal Akuntansi Vo.1 No.1, Mei 2009.

Badan Pemeriksa Keuangan Republik Indonesia, Peraturan Badan Pemeriksa Keuangan Republik Indonesia Nomor 01 tahun 2007 tentang Standar Pemeriksaan Keuangan Negara, Jakarta.

Badan Kepegawaian Daerah Provinsi Sulawesi Utara, Buku Profil Badan Kepegawaian Daerah Provinsi Sulawesi Utara, 2016, Manado.

Badan Pengawasan Keuangan dan Pembangunan (BPKP), 2011, Modul Perencanaan Penugasan Audit, Jakarta.

Daud Zaidi Mat, 2007, The Study of The Audit Expectations Gap In The Public Sector Of Malaysia, Malaysia.

Dinas Kelautan dan Perikanan Provinsi Sulawesi Utara, Buku Profil DinasKelautan dan Perikanan Provinsi Sulawesi Utara, 2016, Manado.

Direktorat Jenderal Perimbangan Keuangan Kementerian Keuangan Republik Indonesia, 2014, Modul Pelatihan Pengelolaan Keuangan Daerah, Jakarta.

Ebimobowei Appah , 2010, An Evaluation Of Audit Expectation Gap : Issues And Challenges, International Journal of Economic Development Research and Investment, Vol.1 Nos. 2 \& 3.

http://acch.kpk.go.id, Korupsi sudah terjadi sejak Perencanaan Anggaran, diakses pada tanggal 3 Februari 2016.

Inspektorat Jenderal Kementerian Dalam Negeri, 2016, Pedoman Pelaksanaan Reviu Dokumen Rencana Pembangunan dan Anggaran Tahunan Daerah, Jakarta.

Inspektorat Provinsi Sulawesi Utara, Buku Pedoman Pengawasan Di Lingkungan Inspektorat Provinsi Sulawesi Utara, 2015, Manado.

Jensen Michael C., William H. Meckling, 1976, Theory of the Firm : Managerial Behavior, Agency Costs and Ownership Structure, Journal of Financial Economics Vol. 3 No. 4, October 1976.

Koh Hian Chye, E. Sah Woo, March 1998, The Expectation Gap in Auditing, Article in Managerial Auditing Journal, 147-154.

Mardiasmo, 2009, Akuntansi Sektor Publik, Penerbit Andi, Yogyakarta.

Muchlisin Riadi, kajianpustaka.com, diakses tanggal 3 Februari 2016.

Onulaka Paul N., 2014, Effect of Audit Expectation Gap in Nigerian Capital Market, International Journal of Accounting and Financial Reporting ISSN 2162-3082, Vol.4, No.2

Pusat Kajian Anti Korupsi (PUKAT) Fakultas Hukum Universitas Gajah Mada, 2014, Trend Corruption Report Periode Januari-Juni 2014, Yogyakarta.

Republik Indonesia, Undang-Undang Dasar 1945, Jakarta.

Republik Indonesia, Undang-undang Nomor 17 tahun 2003 tentang Keuangan Negara, Jakarta.

Republik Indonesia, Undang - Undang Nomor 32 Tahun 2004 tentang Pemerintahan Daerah, Jakarta.

Republik Indonesia, Undang - Undang Nomor 33 Tahun 2004 tentang Perimbangan Keuangan Antara Pemerintah Pusat dan Daerah, Jakarta.

Republik Indonesia, Undang- undang Nomor 25 tahun 2004 tentang Sistem Perencanaan Pembangunan Nasional (SPPN), Jakarta.

Republik Indonesia, Peraturan Pemerintah Nomor 58 tahun 2005 tentang Pengelolaan Keuangan Daerah, Jakarta.

Republik Indonesia, Peraturan Pemerintah Nomor 79 tahun 2005 tentang Pedoman Pembinaan dan Pengawasan Penyelenggaraan Pemerintahan Daerah, Jakarta.

Republik Indonesia, Peraturan Menteri Dalam Negeri Nomor 13 Tahun 2006 tentang Pedoman Pengelolaan Keuangan Daerah, Jakarta.

Republik Indonesia, Peraturan Pemerintah Republik Indonesia Nomor 41 Tahun 2007 tentang Organisasi Perangkat Daerah, Jakarta.

Republik Indonesia, Peraturan Pemerintah Nomor 60 Tahun 2008 tentang Sistem Pengendalian Intern Pemerintah, Jakarta.

Republik Indonesia, Peraturan Menteri Pendayagunaan Aparatur Negara Nomor : 
PER/05/M.PAN/03/2008 tentang Standar Audit APIP, Jakarta.

Rusliyawati, et al., (2008), Penginvestigasian Audit Expectation Gap Pada Sektor Publik, Yogyakarta.

Santoso Hery Budi, 2015, Modul Pelaksanaan Supervisi Audit Intern, Manado

Salehi Mahdi, Ali Mansoury, Zhila Azary, 2009, Audit Independence and Expectation Gap : Empirical Evidences from Iran, International Journal of Economics and Finance Vol.1, No.1, Tahun 2009.

Satori Djam'an, Aan Komariah, 2009, Metodologi Penelitian Kualitatif, Bandung

Setyorini Dhyah, 2005, Evaluasi Empiris Terhadap Persepsi Pemakai Atas Bentuk Laporan Audit Yang Berubah, Jurnal Pendidikan Akuntansi Indonesia Vol.IV No.1, Hal.97-116.

Setyorini Diah A., 2010, Analisis Audit Expectation Gap Pada Pemerintah Daerah (Studi Empiris di Kabupaten Sragen), Surakarta.

STAN, 2007, Modul Program Pendidikan Non Gelar Auditor Sektor Publik "Manajemen Fungsi Audit Internal Sektor Publik", Jakarta.

www.bpkp.go.id, Selayang Pandang tentang Probity Audit Pengadaan Barang dan

Jasa Pemerintah, Jakarta.

Yuliati, Retno, Jaka Winarna, Doddy Setiawan (2007), Expectation Gap antara Pemakai Laporan Keuangan Pemerintah dan Auditor Pemerintah, Simposium Nasional Akuntansi, Makasar.

Yuwono Sony, Dwi Cahyo Utomo, H.Suheiry Zein, H. Azrafiany A.R, 2008, Memahami APBD dan Permasalahannya (Panduan Pengelolaan Keuangan Daerah), Malang

Yandi Dwi Febri, 2013, Analisis Variabel-variabel Audit Expectation Gap atas Hasil Audit BPK (Studi Empiris Pada Pemerintah Kota Jambi , Jambi. 